\title{
A Comparative Study of the Effect of Interlocking Directorates on Merger Target Selection under Different Merger and Acquisition Modes
}

\author{
Qian Zhang \\ School of Economics, Jinan University, Guangzhou, China \\ Email: 995450282@qq.com
}

Received 18 February 2016; accepted 18 March 2016; published 21 March 2016

Copyright (C) 2016 by author and Scientific Research Publishing Inc.

This work is licensed under the Creative Commons Attribution International License (CC BY). http://creativecommons.org/licenses/by/4.0/

\section{(c) (i) Open Access}

\begin{abstract}
This paper, taking the directors of listed companies as point of penetration, studies the effects of interlocking directorates on the company's merger decisions. With a focus on interlocking directorates' influence on the selection of $M$ \& A targets, a Probit regression test was conducted by pairing potential $M \& A$ targets to real acquisition sample according to the industry of the real sample. The innovation of this paper lies in the study of whether there is a significant difference in the effect of interlocking directorates through differentiating various $M \& A$ modes, including horizontal mergers, vertical mergers and mixed mergers. The empirical analysis concludes that when there are interlocking directorates in merger company and potential target company, it is more likely for the potential target to be the object company. What's more, by comparison, when the acquiring company and the target company are from different industries, there is greater impact of interlocking directorates, and the effects are stronger in vertical mergers than in mixed mergers and horizontal mergers.
\end{abstract}

\section{Keywords}

Interlocking Directorates, M \& A, Horizontal Mergers, Vertical Mergers, Mixed Mergers

\section{Introduction}

Corporate governance is the core of listed companies to establish a modern enterprise system, and the Board, as an independent and effective senior management team in the company, is the key to corporate governance. In- 
terlocking directorates refer to board members who are directors of the board in two or more companies at the same time [1]. In recent years, interlocking directorates have become a common phenomenon. According to the research of Cangcong Lu and Shihua Chen, about 72.13\% A-share listed companies in the stock exchange of Shanghai and Shenzhen have at least one interlocking director [2]. Studies have shown that interlocking directorates bridge the two companies in reducing the information asymmetry, reducing transaction costs and changing the mechanism of information communication, thus affecting the decision-making of mergers and the performance of acquisitions [3]. Through a literature study of foreign and domestic publications on interlocking directorates, we found that most researches have focused on the impact of interlocking directorates on decisionmaking and performance of M \& A of a single company. Since there are few studies associating the acquisition company and the acquired company, this paper, taking China's listed companies as samples, attempts to build the association between the acquisition company and the acquired company, studying the influence of the interlocking directorates have on the behavior of company in choosing the object of merger.

$\mathrm{M} \& \mathrm{~A}$ is an act of a company using cash, securities, or other assets to purchase all or most of the assets or shares of another company, in order to control the business and to deprive its legal personality or to change its legal entity [4]-[6]. The modes of merger and acquisition can be divided into horizontal mergers, vertical mergers and mixed mergers according to their industry relations. Horizontal mergers and acquisitions (also called transverse $\mathrm{M} \& \mathrm{~A}$ ) refer to the acquisition of companies in related businesses, whose products are the same with or are technology-related to the products of the merger companies [4]. Vertical mergers and acquisitions (also known as vertical M \& A) refer to acquisitions between companies which have input-output relations, they are buyers and sellers in the phase of producing and continuous selling [6]. Mixed mergers and acquisitions refer to the mergers and acquisitions between unrelated parties, which fall out of the range of horizontal and vertical $\mathrm{M}$ \& A [5]. According to traditional economic theory, horizontal mergers and acquisitions enable enterprises to obtain economies of scale through reduced costs and improved production efficiency; vertical mergers help companies to reduce transaction costs; mixing acquisitions can help companies to avoid risks, expand scale and find new profit growth. Both vertical mergers and mixed mergers are cross industry mergers and acquisitions, but companies involved in mixed and acquisitions face greater obstacles and risks, higher merger cost due to heterogeneity of information barriers between different industries [4]-[13]. This paper will study and discuss the impact of interlocking directorates on the choices of merger object under these three acquisitions modes cases respectively.

\section{Literature Review and Research Hypotheses}

The term Interlocking directorates generally refers to board members who are directors of the board in two or more companies at the same time [1]. However Cai and other scholars have termed two levels in the interlocking directorates relations between the merger company and the acquired company. The first level derived from the director of both the merger company and the target company, and the second level derived from the director of the merger company and the target company also take office in a third company' board [7]. Cai studied these two levels of interlocking directorates and the merger performance respectively and concluded that these two chains will improve the merger performance in a short-term. This paper takes the general definition of interlocking directorates that they are directors in the board of two or more companies at the same time.

There are large number of scholars from home and abroad have studied Mergers \& Acquisitions through researching on the decision-making, motives and performance of mergers. At the same time, many scholars have explored the intrinsic association between Interlocking directorate and corporate mergers and acquisitions.

The first view is that the interlocking directorates of both sides have negative effect on the performance of merger. Ishii and Xuan believe that the social relation between both sides leads to familiarity bias (Familiarity Bias) of reducing the standard of merger company's due diligence towards potential target companies, overestimating mergers and acquisitions synergies, abandoning or overlooking other potential better opportunity. Such bias undermines the value of mergers and acquisitions. As shown through the empirical test that the relations between the board of both companies are negatively related to the performance of the merger company, the acquired company and the entity after the M \& A [8]. Wu believes that Interlocking Directorate between the two sides will increase agency conflicts. The interlocking director, who has the fiduciary responsibility to shareholders, is involved in the decision-making of mergers and acquisitions. Driven by the motives of maximizing personal wealth, he is likely to increase the possibility of benefit one company while compromise the other, or 
cause damage to the value of both companies [9]. Meanwhile, Jensen discovered that personal relations among directors established by the interlocking directorates may hinder decision-making of acquisitions, and that executives of both sides are likely to make decisions harmful to the value and the performance of M \& A by seeking their own interests [10]. Le Wei took Chinese listed companies as samples and found that the greater the network center of the board, the lower the performance of M \& A [14].

The second view is that the interlocking directorates have a positive impact on corporate mergers and acquisitions. Previous studies were mainly based on social mosaic theory, the theory of inter-organizational imitation and messaging perspective. Granovettor was the first to put up social mosaic theory that the relations in the social structure have great influence on the companies' economic behavior and economic consequences. The social relations of board members, namely the corporate social relations presented by the interlocking directorates, will inevitably have a major impact on business decision-making and enterprise value [15].

Haunschild based his study on inter-organizational imitation theory, took American listed companies’ M \& A events as samples, he found that between two companies of Interlocking Directorate relations, one will mimic the $\mathrm{M} \& \mathrm{~A}$ activity that has occurred in the other company in making its $\mathrm{M} \& \mathrm{~A}$ decisions, including the frequency and the type of mergers and acquisitions. Such behavior leads to a high degree of similarity in M \& A of interlocking directorates companies. Haunschild then took American companies as a sample, he found that the less certain the merger company is about the value of the targeted company, the greater the influence of previous M \& A activities of interlocking directorates related Company has on its M \& A pricing [16] [17]; Shihua Chen took Chinese listed companies as samples to explore the role of links between company executives in decision-making of premium in the company's M \& A, and he found that the imitation existed in company's decision-making of premium in M \& A. These studies are mainly based on inter-organizational imitation theory to discover the effect of the links among boards of companies on their merger decision.

Other scholars took the perspective of information transmission to explore the impact of interlocking directorates or the degree of network center of board of directors of both parties have on the M \& A activity. Schonlau took listed companies in the United States as samples for research from the perspective of information transmission. He found that the higher the centrality of the company's directors Network the more excellent information transmission mechanism the company has. With lower information asymmetry, such company is able to gain information about other company at relatively small cost, and thus it is more likely to initiate merger and acquisition activity. On the other hand, the more transparent of information disclosure, the easier for other companies to access the company's information, thus making it more likely to be merged. It is true to both the acquiring company and the target company that the higher the centrality of the company's directors Network, the better the performance of M \& A will be in the long-term [18]. Cukurova built a private information model and held that there is a greater possibility of companies with interlocking directorates relations to the acquiring company to become the target company. Taking the data in the United States as sample, he verified this inference through an empirical test [19].

In summary, previous studies on mergers and acquisitions of companies share interlocking directorates are characterized by three distinct features:

1) There are two branches, one studies the mimic behavior of the acquired company; the other studies the effect that direct relations of interlocking directorates have on the decision and economic consequences of acquisition.

2) There is a majority research on the effect of interlocking directorates has on merger decisions while less study of cross-border mergers and acquisitions.

3) Reach samples are mainly listed companies in developed countries, especially in the US. There is very little research on China.

Davies believes the steps of determining the target company for the acquiring company include the formation of the acquisition plan, of the list of potential targets, of strategic control charts, the understanding of their own shortcomings, the reduction of listed potential target companies, the summarizing and scoring of potential targets companies to determine the final acquisition targets. He believes that the Board plays an important role in determining the target company and all the members of the board of the acquiring company are involved in the process of searching for and identify target companies to make the appropriate decisions [20]. Bruner believes it takes several months or even longer for the acquiring company to determine the target company, for any impact factor of costs of searching and due diligence are economic significant [21]. Stuart's study has shown that interlocking directorates reduce information asymmetry in transactions of control of private equity. Companies of 
interlocking directorates relations are more likely to become targets [22]; Cukurova took American listed companies as samples and found that, by comparison with other companies, companies of interlocking directorates relations with the acquiring company are more likely to be acquired. And according to the social mosaic theory, interlocking directorates have great influence on important decisions for business activities including mergers and acquisitions [23].

Therefore, we believe that interlocking directorates have a positive impact on important decision-making processes including mergers and acquisitions, and in the cases of other situation being the same, interlocking directorates companies are more likely to close the deal.

$\mathrm{H}$ : Interlocking directorates contribute to decision-making of mergers and acquisitions, under the same conditions, the deal is more likely to occur between interlocking directorates companies.

Meanwhile, in different M \& A mode there are significant differences in the motives of M \& A and in the degree of information asymmetry. Thus Interlocking Directorates effect is likely to be different in different acquisition modes.

\section{Study Design}

\subsection{Sample Selection and Data Sources}

In this paper, data are processed through CSMAR database and Wind Information. CSMAR database has a statistical system of M \& A events of Listed Companies. Since the data of executives in CSMAR sample database started from 1999, the information of ownership structure under corporate governance can be dated back to 2003, and the desired financial data of sample acquisition and management should count from the previous year, this paper selected sample interval of 2004-2014. Merger events screening process is as follows: (1) both acquiring company and the target company are A-share listed companies in China; (2) the acquiring companies of financial sector are excluded in the sample; (3) acquisition types of backdoor listing, debt restructuring, capital split, replacement of assets, share repurchases and divestitures are excluded; (4) acquisitions type of associated acquisition is also excluded. After screening, 118 samples remain, 54 of which are horizontal mergers and acquisitions, 25 vertical mergers and 39 mixed mergers. Then match each real acquisition target to potential acquisition target in the same industry, exclude target companies with market value of more than $130 \%$ of the real target, a total of 4610 paired samples are obtained, 2479 of which are horizontal samples, 981 vertical samples and 1150 mixed samples. The total number of samples is 4728.

\subsection{Variable Selection}

According to Bodnaruk, Gaoliang Tian [24] [25], in reference to mergers events occurred between listed companies, acquired company is the real target companies and its value is 1 . Pairing companies, namely the potential target companies, are A-share listed companies of a total market capitalization not more than $130 \%$ of the total of the real target companies in the same industry. Their value is set to be 0 . Thus for each real deal, there are a series of potential target companies.

1) The independent variable

The independent variable is the number of interlocking directorates' directors. So far, most of the studies have only studied the influence of the presence of interlocking directorates, while this paper conducted a matching study of the number of directors.

\section{2) Control variables}

In consideration that the number of directors, company size, growth, liquidity and profitability have an impact on companies' M \& A decisions, we select the scale of board, the total market value, debt equity ratio, ROE, the main revenue growth rate, the proportion of the largest shareholder, the proportion of the top ten shareholders, Tobin's Q ratio, earnings, Beta value, year, etc. as control variables. Table 1 lists the definitions and calculation methods of these variables. Before empirical test all explanatory variables had gone through pairwise correlation test and we found that variable Tobin's Q had collinear relationship with several other variables, so this study excluded variable Q.

\subsection{Model}

Referring to the study of Bodnaruk and Gaoliang Tian while considering the actual situation of M \& A activities 
Table 1. Variable definitions.

\begin{tabular}{|c|c|c|c|}
\hline Type & Index & Variable name & Variable definition and calculation method \\
\hline $\begin{array}{l}\text { dependent } \\
\text { variable }\end{array}$ & \multicolumn{2}{|c|}{$\begin{array}{l}\text { Purpose of M \& } \text { Target } \\
\text { A }\end{array}$} & $\begin{array}{l}\text { Dummy variable. The value is } 1 \text { if the sample is the real } \mathrm{M} \& \mathrm{~A} \text { target, otherwise the } \\
\text { value is } 0 .\end{array}$ \\
\hline \multirow[t]{5}{*}{$\begin{array}{l}\text { independent } \\
\text { variable }\end{array}$} & $\begin{array}{l}\text { interlocking } \\
\text { directorates }\end{array}$ & NumInterlock & $\begin{array}{l}\text { The number of interlocking directorates at the end of the previous year of the first } \\
\text { announcement day }\end{array}$ \\
\hline & company size & Size & $\begin{array}{l}\text { Relative total assets scale. The total assets of target divided by total assets of the } \\
\text { acquiring company at the end of the previous year of first announcement day }\end{array}$ \\
\hline & Boardsize & Numdir & $\begin{array}{l}\text { The board size of target company at the end of the previous year of the first } \\
\text { announcement day }\end{array}$ \\
\hline & \multirow{2}{*}{$\begin{array}{l}\text { investment } \\
\text { value }\end{array}$} & Q & $\begin{array}{l}\text { The Tobin's Q ratio of target company at the end of the previous year of the first } \\
\text { announcement day (excluded) }\end{array}$ \\
\hline & & $\mathrm{PE}$ & $\begin{array}{l}\text { PE ratio of target company at the end of the previous year of the first announcement } \\
\text { day }\end{array}$ \\
\hline \multirow{7}{*}{$\begin{array}{l}\text { control } \\
\text { variables }\end{array}$} & Profitability & ROE & $\begin{array}{l}\text { Return on equity of target company at the end of the previous year of the first } \\
\text { announcement day }\end{array}$ \\
\hline & Growth & MRGR & $\begin{array}{l}\text { Main business revenue growth rate of target company at the end of the previous year } \\
\text { of the first announcement day }\end{array}$ \\
\hline & Leverage ratio & DER & $\begin{array}{l}\text { Debt equity ratio of target company at the end of the previous year of the first } \\
\text { announcement day }\end{array}$ \\
\hline & \multirow{2}{*}{$\begin{array}{l}\text { ownership } \\
\text { structure }\end{array}$} & Top1 & $\begin{array}{l}\text { The proportion of the largest shareholder of target company at the end of the } \\
\text { previous year of the first announcement day }\end{array}$ \\
\hline & & Top10 & $\begin{array}{l}\text { The proportion of the top ten shareholders of target company at the end of the } \\
\text { previous year of the first announcement day }\end{array}$ \\
\hline & Stock Volatility & Beta & Beta value of target company during the previous year of the first announcement day \\
\hline & Year & Year & The year of the first announcement \\
\hline
\end{tabular}

Footnote: the variable of Tobin's Q has been excluded for its collinear relationship with several other variables.

in China, this study use probit regression model to test the hypothesis.

$$
\begin{aligned}
& \text { Target }=\alpha_{0}+\alpha_{1} \text { NumInterlock }+\alpha_{2} \text { Size }+\alpha_{3} \text { Numdir }+\alpha_{4} P E+\alpha_{5} \text { ROE }+\alpha_{6} \text { MRGR } \\
& +\alpha_{7} \text { DER }+\alpha_{8} \text { Top } 1+\alpha_{9} \text { Top } 10+\alpha_{10} \text { Beta }
\end{aligned}
$$

First, the whole sample was tested to investigate the impact of interlocking directorates on selecting acquisition targets. After this, a comparison study was conducted respectively to the three sub-samples of lateral mergers, vertical mergers and mixed, using the above model.

\section{Empirical Analysis}

\subsection{Descriptive Statistical Analysis}

Among the total of 118 acquisitions incidents of listed companies during 2004 to 2014, 30 are of companies with interlocking directorates relations. Seen from Table 2, in the year 2014, mergers and acquisitions is the most frequent, in 2006 and 2007 the numbers of mergers and acquisitions are also high. Horizontal M \& A mode had the largest number, followed by mixed, the number of vertical mergers is the least. Since the three kinds of M \& A mode has no rules of distribution, the decision of mergers and acquisitions of listed companies is still based on strategic starting point. In 2006 acquisitions of listed companies had a small outbreak, quiet for a few years, in 2014 listed companies experienced a concentrated outbreak in China. The number of mergers and the number of vertical mergers and the number of mixed mergers has seen a big increase, which indicates that China's stock market system has gradually improved, enterprise management is becoming more mature, diversified business is gradually forming, corporate heterogeneous inter-industry mergers and acquisitions are becoming more common, cross-border M \& A project reflects the increasingly diversified development of China's listed companies.

Table 3 is the descriptive statistics of the mean value and the standard deviation of the variables of the full sample and the three sub-samples. Since the size of the company has been brought under control in the sample selection, it needs no longer descriptive statistical analysis. In this study, interlocking directorates samples and paired samples, horizontal mergers and vertical mergers, vertical mergers and mixed were pairwise tested 
Table 2. Real Sample descriptive statistics.

\begin{tabular}{|c|c|c|c|c|c|c|c|c|}
\hline \multirow{2}{*}{ Year } & \multicolumn{4}{|c|}{ Total sample } & \multicolumn{4}{|c|}{ Interlocking directorates sample } \\
\hline & Horizontal & Vertical & Mixed & Total & Horizontal & Vertical & Mixed & Total \\
\hline 2014 & 6 & 9 & 8 & 23 & 3 & 2 & 0 & 5 \\
\hline 2013 & 8 & 2 & 0 & 10 & 3 & 2 & 0 & 5 \\
\hline 2012 & 8 & 1 & 1 & 10 & 1 & 0 & 0 & 1 \\
\hline 2011 & 3 & 1 & 3 & 7 & 0 & 1 & 0 & 1 \\
\hline 2010 & 4 & 0 & 2 & 6 & 1 & 0 & 1 & 2 \\
\hline 2009 & 4 & 1 & 3 & 8 & 0 & 0 & 0 & 0 \\
\hline 2008 & 2 & 2 & 4 & 8 & 1 & 1 & 1 & 3 \\
\hline 2007 & 4 & 2 & 6 & 12 & 2 & 2 & 1 & 5 \\
\hline 2006 & 7 & 3 & 4 & 14 & 1 & 1 & 2 & 4 \\
\hline 2005 & 4 & 4 & 0 & 8 & 1 & 2 & 0 & 3 \\
\hline 2004 & 4 & 0 & 8 & 12 & 0 & 0 & 1 & 1 \\
\hline Total & 54 & 25 & 39 & 118 & 13 & 11 & 6 & 30 \\
\hline
\end{tabular}

Table 3. Variable descriptive statistics.

\begin{tabular}{|c|c|c|c|c|c|c|c|c|}
\hline & \multicolumn{2}{|c|}{ Total sample } & \multicolumn{2}{|c|}{ Horizontal sample } & \multicolumn{2}{|c|}{ Vertical sample } & \multicolumn{2}{|c|}{ Mixed sample } \\
\hline & Mean value & $\begin{array}{l}\text { Standard } \\
\text { deviation }\end{array}$ & Mean value & $\begin{array}{l}\text { Standard } \\
\text { deviation }\end{array}$ & Mean value & $\begin{array}{l}\text { Standard } \\
\text { deviation }\end{array}$ & Mean value & $\begin{array}{l}\text { Standard } \\
\text { deviation }\end{array}$ \\
\hline Target & 0.0250 & 0.1560 & 0.0213 & 0.1445 & 0.0249 & 0.1558 & 0.0328 & 0.1782 \\
\hline NumInterlock & 0.0461 & 0.2909 & 0.0655 & 0.3483 & 0.0308 & 0.2524 & 0.0177 & 0.1497 \\
\hline Numdir & 9.1760 & 1.9664 & 9.1421 & 1.9521 & 9.0626 & 1.8151 & 9.3440 & 2.1059 \\
\hline PE & 79.6115 & 400.5179 & 82.7038 & 436.1921 & 71.9852 & 302.6755 & 79.4769 & 393.9563 \\
\hline ROE & 0.0091 & 1.4187 & 0.0247 & 1.2978 & -0.0193 & 1.2305 & 0.0002 & 1.7714 \\
\hline MRGR & 0.3741 & 9.5209 & 0.5224 & 9.4699 & 0.2741 & 9.3299 & 0.1426 & 9.1862 \\
\hline DER & 1.5824 & 11.2284 & 1.5315 & 5.0957 & 1.6002 & 4.7742 & 1.6770 & 20.6597 \\
\hline Top1 & 35.4738 & 15.4872 & 35.3582 & 15.2211 & 36.5856 & 15.7260 & 34.7794 & 15.8056 \\
\hline Top10 & 54.7997 & 15.0919 & 54.7730 & 15.1340 & 55.8591 & 14.5615 & 53.9606 & 15.3975 \\
\hline Beta & 1.0963 & 0.2398 & 1.1051 & 0.2345 & 1.1094 & 0.2414 & 1.0668 & 0.2471 \\
\hline
\end{tabular}

through independent T-test. Differences only occurred in interlocking directorates data and ROE data while no significant differences between other variables.

\subsection{Probit Empirical Results}

Empirical result of estimated interlocking directorates' variables coefficients was 0.704 in the Probit test of the full sample. It was $1 \%$ level significantly, indicating that interlocking directorates have a positive impact on $\mathrm{M}$ \& A. In the cases of other situations to be the same, companies planning to merger are more likely to choose companies with interlocking directorates as acquisition targets. The empirical results are shown in Table 4.

Estimated interlocking directorates coefficients obtained from the three sub-samples are all $>0$, and are in the $1 \%$ significance level. It is noteworthy that the estimated coefficients interlocking directorates of vertical mergers and mixed mergers are significantly greater than horizontal mergers and acquisitions, which verifies the previous conjecture in this paper, that between heterogeneous industries, the acquiring company is more likely to choose its interlocking directorates related companies as acquisition targets. Although many, in the corporate 
Table 4. Empirical result of full sample and sub-samples.

\begin{tabular}{|c|c|c|c|c|}
\hline & Total sample & Sub-sample 1 (horizontal) & Sub-sample 2 (vertical) & Sub-sample 3 (mixed) \\
\hline NumInterlock & $\begin{array}{c}0.704 * * * \\
(0.000)\end{array}$ & $\begin{array}{c}0.554 * * * \\
(0.001)\end{array}$ & $\begin{array}{c}1.327 * * * \\
(0.000)\end{array}$ & $\begin{array}{c}1.161^{* * *} \\
(0.000)\end{array}$ \\
\hline Size & $\begin{array}{c}0.002 * \\
(0.067)\end{array}$ & $\begin{array}{c}0.033^{*} \\
(0.067)\end{array}$ & $\begin{array}{c}0.004 * \\
(0.096)\end{array}$ & $\begin{array}{l}0.002^{* *} \\
(0.042)\end{array}$ \\
\hline Numdir & $\begin{array}{c}0.026 \\
(0.202)\end{array}$ & $\begin{array}{c}0.036 \\
(0.228)\end{array}$ & $\begin{array}{l}0.019 \\
(0.696)\end{array}$ & $\begin{array}{l}-0.017 \\
(0.655)\end{array}$ \\
\hline PE & $\begin{array}{l}0.001^{* *} \\
(0.031)\end{array}$ & $\begin{array}{c}0.001^{*} \\
(0.071)\end{array}$ & $\begin{array}{l}0.001 * \\
(0.082)\end{array}$ & $\begin{array}{c}-0.001^{* *} \\
(0.026)\end{array}$ \\
\hline ROE & $\begin{array}{c}0.043^{* * *} \\
(0.005)\end{array}$ & $\begin{array}{c}0.023 * * * \\
(0.009)\end{array}$ & $\begin{array}{c}0.211^{* * *} \\
(0.002)\end{array}$ & $\begin{array}{c}0.040^{* * *} \\
(0.007)\end{array}$ \\
\hline MRGR & $\begin{array}{c}0.011^{*} \\
(0.093)\end{array}$ & $\begin{array}{c}0.001 * \\
(0.091)\end{array}$ & $\begin{array}{c}0.017 * \\
(0.088)\end{array}$ & $\begin{array}{c}0.019 * \\
(0.081)\end{array}$ \\
\hline DER & $\begin{array}{l}-0.005 \\
(0.555)\end{array}$ & $\begin{array}{l}-0.001 \\
(0.955)\end{array}$ & $\begin{array}{c}0.007 \\
(0.891)\end{array}$ & $\begin{array}{l}-0.011 \\
(0.495)\end{array}$ \\
\hline Top1 & $\begin{array}{c}-0.002 \\
(0.532)\end{array}$ & $\begin{array}{c}0.003 \\
(0.561)\end{array}$ & $\begin{array}{l}-0.013 \\
(0.157)\end{array}$ & $\begin{array}{l}-0.005 \\
(0.455)\end{array}$ \\
\hline Top10 & $\begin{array}{l}0.007^{* *} \\
(0.025)\end{array}$ & $\begin{array}{l}0.009 * * \\
(0.037)\end{array}$ & $\begin{array}{l}0.005^{*} \\
(0.053)\end{array}$ & $\begin{array}{l}0.007^{* *} \\
(0.032)\end{array}$ \\
\hline Beta & $\begin{array}{c}0.245 \\
(0.176)\end{array}$ & $\begin{array}{c}0.163 \\
(0.545)\end{array}$ & $\begin{array}{c}0.099 \\
(0.824)\end{array}$ & $\begin{array}{l}0.753^{* *} \\
(0.025)\end{array}$ \\
\hline a 0 & $\begin{array}{c}-2.869 * * * \\
(0.000)\end{array}$ & $\begin{array}{c}-3.258^{* * *} \\
(0.000)\end{array}$ & $\begin{array}{c}-2.281^{* * *} \\
(0.003)\end{array}$ & $\begin{array}{c}-2.84^{* * *} \\
(0.000)\end{array}$ \\
\hline $\mathrm{X} 2$ & 0.299 & 0.271 & 0.469 & 0.410 \\
\hline
\end{tabular}

Footnote: the value in bracket under each parameter is $\mathrm{P}$ value of significance level. *, **, ${ }^{* * *}$ stand for significance level of $1 \%, 5 \%$ and $10 \%$ respectively.

articles, state that related directors are abstained from voting on the board, the chairman and other executives cannot hold important positions in competing companies, the impact of related directors wasn't eliminated, in many cases, in the process of companies reaching inter-related agreement. However, in horizontal M \& A interlocking directorates can only play a limited role. Company choosing horizontal M \& A are more probably out of ambitious expansion and strategic consideration.

For mergers between enterprises from heterogeneous industries, estimated interlocking directorates coefficients of vertical mergers are greater than that of mixed. It should also be noted that the greater industries difference doesn't necessarily mean the greater impact of interlocking directorates on M \& A Target Selection. Due to the larger trade barriers, information asymmetry in Mixing $M$ \& A, the acquisition costs and risks are higher. Compared to vertical mergers, mixed acquisitions require a little more rational decision-making and more from a strategic point of view in analyzing acquisition targets.

\subsection{Robustness Test}

\section{1) Variable Collinearity}

After removing the variable Tobin's $Q$, all of the remaining explanatory variables were studied through pairwise correlation test and there weren't significant correlation between them. VIF values of all variables are less than 2 and the model wasn't multicollinear.

\section{2) Selection Error in Matching the Sample}

Companies from the same industry of acquired company and with market capitalization $\leq 130 \%$ of that of real object of corporate mergers and acquisitions are chosen as potential acquisition targets. Referring Bodnaruk, Gaoliang Tian's study, companies with a real market value of $80 \%-120 \%, 70 \%-130 \%$ of sample companies' value is chosen for repeat test, and the result was the same.

\section{3) The Impact of Interlocking Directorates Types}

Board members may serve in other positions in the company, their being independent directors or chairman in the board allows them to play different roles in Board decision-making as well as in business management. Thanks to the fact that the number of interlocking directorates in the real sample is not large, the board members 
were able to be checked one by one. Through this, we found it rare for interlocking directors to serves in other important position of other companies. Seeing that the proportion is less than $10 \%$, we conclude that interlocking directorates types' impact on test model is limited.

\section{Conclusions}

The main contributions of this paper are as follows: (1) As most existing studies are based on the data of American market, this paper chose A-share listed companies in China as samples. Cross-border mergers and acquisitions were studied in this paper. All this makes this article the earlier studies on interlocking directorates' influence on corporate decisions and on company's M \& A decision. (2) Previous studies focused more on acquiring company than acquired company. (3) There are relatively few studies on M \& A decision conducting comparative studies on different $\mathrm{M} \& \mathrm{~A}$ modes.

Through this study, it proves that interlocking directorates can help company to choose potential acquisition target from interlocking directorates related companies, which is of great significance in corporate governance and major decision-making. In the current situation that Chinese market has not yet fully marketized and the transmission of information is not sufficient, the board of directors of listed companies can potentially play a role outside the system to affect the operating decisions. Mergers and acquisitions of companies in different industries facing higher costs and risks, enterprises have a tendency to use interlocking directorates to reduce costs and risks. But when the industry is completely heterogeneous, interlocking directorates' influence declines. In such case, the enterprise will take more consideration of qualified acquisition targets in order to select the best fit enterprise as acquisition targets.

\section{References}

[1] Mizruchi, M.S. (1996) What Do Interlocks Do? An Analysis, Critique, and Assessment of Research on Interlocking Directorates. Annual Review of Sociology, 22, 271-298. http://dx.doi.org/10.1146/annurev.soc.22.1.271

[2] Chen, S.H. and Lu, C.C. (2013) Inter Firm Executive Connection and Premium Decision of Merger and Acquisition. Management World, 5, 144-156.

[3] Darmadi, S. and Gunawan, R. (2013) Underpricing, Board Structure, and Ownership: An Empirical Examination of Indonesian IPO Firms. Managerial Finance, 39, 181-200. http://dx.doi.org/10.1108/03074351311294016

[4] Farrel, J. and Shapiro, C. (1990) Horizontal Mergers: An Equilibrium Analysis. American Economic Review.

[5] Muller, D.C. (1969) A Theory of Conglomerate Merger. Quarterly Journal of Economics, 83, 643-659. http://dx.doi.org/10.2307/1885454

[6] Williamson, O.E. (1971) The Vertical Integration of Production: Market Failure Considerations. The America Economic Review.

[7] Cai, Y. and Sevilir, M. (2010) Board Connections and M\&A transactions. Journal of Financial Economics, 103, 327349.

[8] Ishii, J. and Xuan Y. (2010) Acquirer-Target Social Ties and Merger Outcomes. Journal of Financial Economics, 112, 344-363. http://dx.doi.org/10.2139/ssrn.1361106

[9] Wu, Q. (2011) Information Conduit or Agency Cost: Top Management and Director Interlock between Target and Acquirer. Working Paper.

[10] Jensen, M. (1086) Agency Costs of Free Cash Flow, Corporate Finance and Takeovers. American Economic Review, 76, 323-339.

[11] Li, G.Z. (2003) Horizontal Merger Behavior and Strategy of Enterprises. Journal of Liaoning Administration College.

[12] Ren, H.X. (2004) Merger and Acquisitions. China Renmin University Press.

[13] Wan, C.L. (2002) Research on China M \& A. Guosen Securities Research Report.

[14] Wei, L., Zhang, Q.S. and Zhao, L.B. (2012) An Empirical Study on the Influence of Chain Director Network on Enterprise M \& A. Luojia Management Review, 1, 87-96.

[15] Granovettor, M. (1985) Economic Action and Social Structure: The Problem of Embeddedness. American Journal of Sociology, 91, 481-510. http://dx.doi.org/10.1086/228311

[16] Haunschild, P.R. (1994) How Much Is That Company Worth? Interorganizational Relationships, Uncertainty, and Acquisition Premiums. Administrative Science Quarterly, 39, 391-411. http://dx.doi.org/10.2307/2393296

[17] Haunschild, P.R. (1993) Interorganizational Imitation: The Impact of Interlocks on Corporate Acquisition Activity. 
Administrative Science Quarterly, 38, 564-592. http://dx.doi.org/10.2307/2393337

[18] Schonlau, R.J. and Singh, P.V. (2009) Board Networks and Merger Performance. Brigham Young University, Provo.

[19] Cukurova, S. (2012) Interlocking Directors and Target Selection in Mergers and Acquisitions. Aalto University, Helsinki.

[20] Davies, M. (2011) Pick a Winner: How to Select the Right Acquisition Target. CMA Magazine, 85, 18-19.

[21] Bruner, R.F. (2004) Applied Mergers and Acquisitions. Wiley, Hoboken, NJ, 123-150.

[22] Stuart, T.E. and Yim, S. (2010) Board Interlocks and the Propensity to Be Targeted in Private Equity Transactions. Journal of Financial Economics, 97, 174-189. http://dx.doi.org/10.1016/j.jfineco.2010.03.012

[23] Cukurova, S. (2012) Interlocking Directors and Target Selection in Mergers and Acquisitions. Aalto University, Helsinki.

[24] Bodnaruk, A., Massa, M. and Simonov, A. (2009) Investment Banksas Insiders and the Market for Corporate Control. The Review of Financial Studies, 22, 4989-5026. http://dx.doi.org/10.1093/rfs/hhp043

[25] Tian, G.L., Li, L.C. and Qi, B.L. (2011) Interlocking Directorate, Financial Performance and Firm Value. Journal of Management Science, 24, 13-24. 